\title{
Urogenital, maternal and neonatal isolates of Haemophilus influenzae: identification of unusually virulent serologically non-typable clone families and evidence for a new Haemophilus species
}

\author{
R. Quentin, ${ }^{1 *}$ A. Goudeau, ${ }^{1}$ R. J. Wallace, JR, ${ }^{2}$ A. L. Smith, ${ }^{3}$ R. K. Selander ${ }^{4}$ and \\ J. M. MUSSER ${ }^{4,5}$ \\ ${ }^{1}$ Département de Microbiologie Médicale et Moléculaire, URA CNRS 1334, Centre Hospitalier et Universitaire, \\ Bretonneau, 37044 Tours Cedex, France \\ ${ }^{2}$ Department of Microbiology, University of Texas Health Science Center at Tyler, Texas, USA \\ ${ }^{3}$ Division of Infectious Diseases, Children's Hospital and Medical Center, Seattle, Washington, USA \\ ${ }^{4}$ Department of Biology, Mueller Laboratory, Pennsylvania State University, University Park, Pennsylvania, USA \\ ${ }^{5}$ Department of Pathology and Laboratory Medicine, Hospital of the University of Pennsylvania, 3400 Spruce Street, \\ Philadelphia, Pennsylvania, USA
}

(Received 12 January 1990; revised 27 February 1990; accepted 5 March 1990)

\begin{abstract}
A collection of 117 strains of Haemophilus influenzae, including 112 non-typable isolates recovered predominantly in the USA and France from genital, obstetric and neonatal sources, was characterized by the electrophoretic mobilities of 10 metabolic enzymes. Eighty-six distinctive multilocus chromosomal genotypes (electrophoretic types, ETs) were distinguished on the basis of allele profiles at the enzyme loci. Isolates of five allied biotype IV ETs were highly divergent from all other strains and hybridization of chromosomal DNA revealed that they undoubtedly represent a previously unrecognized species of Haemophilus. Isolates representing these ETs were recovered predominantly from obstetric infections and serious neonatal diseases and apparently possess specific tropism for the genital tract. Strains of these five ETs were present in samples from both the USA and France, but only in the USA did they cause bacteraemia and meningitis, an occurrence which probably reflects differences in patient management between the two countries. Although strains assigned to $\mathrm{H}$. influenzae (sensu stricto) were strongly polymorphic in multilocus enzyme genotype, $69 \%$ of isolates recovered from patients with meningitis and/or septicaemia were assigned to only two clone families, a result suggesting that some serologically nontypable strains of $\boldsymbol{H}$. influenzae originating from the genital tract are unusually virulent.
\end{abstract}

\section{Introduction}

Genital and mother-infant infections, neonatal septicaemia and meningitis episodes caused by Haemophilus influenzae were reported with increased frequency in the 1980s (Wallace et al., 1983; Kleiman et al., 1983; Friesen \& Cho, 1986; Quentin et al., 1987). Unlike strains recovered from invasive episodes in children occurring after the first month of life, those isolated from neonates are usually non-typable. Currently, $5-8 \%$ of cases of invasive neonatal diseases in some states of the USA are caused by non-encapsulated $H$. influenzae (Wallace $e t$ al., 1983; Campognone \& Singer, 1986), and these infections are associated with significant morbidity and mortality.

Abbreviation: ET, electrophoretic type.
In striking contrast, in a six-year study in France, only a single case of $H$. influenzae neonatal meningitis was recorded (caused by a serotype b strain) and no episodes of neonatal or maternal sepsis were recorded (Quentin et al., 1989).

Characterization of outer-membrane proteins of genital and neonatal isolates from France and the USA by SDS-PAGE revealed two phenotypic populations of $H$. influenzae. One population comprised $H$. influenzae strains of all biotypes and appeared quite similar to the heterogeneous population isolated from upper respiratory tract infection. A second population was composed of $H$. influenzae strains of biotype IV, and was relatively homogeneous in outer-membrane protein type. Comparison of $H$. influenzae strains isolated from patients in these countries did not identify major phenotypic 
differences that would account for the more favourable outcomes observed in French patients (Quentin et al., 1989).

In addition, in the course of a study of the genetic relationships of serologically non-typable and serotype $b$ $H$. influenzae isolates by multilocus enzyme electrophoresis, four unencapsulated strains were identified which were genetically highly divergent from all others examined and were hypothesized to be specifically distinct (Musser et al., 1986a). These strains were closely similar in chromosomal genome, were of biotype IV, and had originated from cases of neonatal bacteraemia or obstetric infections.

The objectives of the research reported here were to examine further the molecular epidemiology, genetic diversity and relatedness of isolates of $H$. influenzae from neonatal, maternal and urogenital sources by assaying allelic variation in a sample of chromosomal enzyme loci. Specifically, our goals were to (i) assess the frequency of occurrence of strains with highly divergent genotypes, (ii) ascertain the genetic relationship of these divergent genotypes with respect to the species $H$. influenzae, and (iii) examine associations of distinctive bacterial genotypes and systemic infections.

\section{Methods}

Bacterial isolates. A collection of 117 strains of $H$. influenzae, isolated in the 1970s and 1980s from genital and neonatal infections, was used. Eighty isolates were recovered from patients in the Bretonneau University Hospital in Tours, France; 37 cultures originated from North America, of which 36 were from the USA and one from Canada. The anatomic origins of the isolates are listed in Table 1. Some of the isolates have been described previously (Wallace et al., 1983; Kleiman et al., 1983; Campognone \& Singer, 1986; Musser et al., 1986a; Quentin et al., 1987, 1989).

Serotyping. Isolates from France and Canada were serotyped upon isolation with co-agglutination reagents (Phadebact-Haemophilus test; Pharmacia) and controlled by slide agglutination and/or countercurrent immunoelectrophoresis with commercial type-specific rabbit antisera prepared against $H$. influenzae capsular types a to $\mathrm{f}$ (Difco). Isolates from the USA were serotyped by slide agglutination with typespecific commercial antisera (Difco), or with type-specific antisera prepared by the Centers for Disease Control, Atlanta, Georgia, USA (Wallace et al., 1983). Most isolates from the USA were also serotyped by countercurrent immunoelectrophoresis with uncentrifuged culture broth and type-specific antisera (type b, Hyland Diagnostics, Deerfield, Illinois, USA; types a, c, d, e and f, Burroughs-Wellcome) (Wallace et al., 1983).

Biotyping. All isolates from Canada and France were biotyped with the API 20E system (API System, Montalieu Vercieu, France), as described by Holmes et al. (1982). Isolates from the USA were tested for urease activity, indole production and ornithine decarboxylase activity (Kilian, 1976, 1980) with the Minitek system (BBL Microbiology Systems), as described previously (Wallace et al., 1983).

Enzyme electrophoretic analysis. Each isolate was grown overnight at $37^{\circ} \mathrm{C}$ in $150 \mathrm{ml}$ brain heart infusion broth supplemented with NAD and haemin, each at $2 \mu \mathrm{g} \mathrm{ml}^{-1}$. Cells were harvested by centrifugation,
Table 1. Collection locality and anatomic site of recovery for 117 genital and neonatal isolates of $\mathrm{H}$. influenzae

\begin{tabular}{|c|c|c|c|}
\hline \multirow[b]{2}{*}{ Anatomic site } & \multicolumn{2}{|c|}{ Country } & \multirow[b]{2}{*}{ Tota } \\
\hline & France & USA & \\
\hline $\begin{array}{l}\text { Gastric fluid of neonates heavily } \\
\text { colonized }\end{array}$ & 19 & 5 & 24 \\
\hline Placenta & & 1 & 1 \\
\hline Cerebrospinal fluid of neonates & 1 & $3^{*}$ & 4 \\
\hline Blood of neonates $\dagger$ & & 18 & 18 \\
\hline Blood of mother $\ddagger$ & & 4 & 4 \\
\hline $\begin{array}{l}\text { Curettage product during septic } \\
\text { miscarriages }\end{array}$ & 4 & & 4 \\
\hline Endouterine samples & 24 & & 24 \\
\hline Peritoneal fluid during salpingitis & 5 & & 5 \\
\hline \multicolumn{4}{|l|}{ Surgically obtained pus: } \\
\hline Bartholinitis & 5 & 1 & 6 \\
\hline Orchiepididymitis & 1 & & 1 \\
\hline Rectal abscess (male) & & 1 & 1 \\
\hline Scrotal abscess & & 1 & 1 \\
\hline Vaginal and endocervical swabs & 16 & 3 & 19 \\
\hline Urethral swabs (male) & 2 & & 2 \\
\hline Sperm culture & 3 & & 3 \\
\hline Total & 80 & 37 & 117 \\
\hline
\end{tabular}

* One strain was from Canada.

$\dagger$ In two cases, blood cultures of mother were also positive.

$¥$ With negative blood cultures in the neonates.

suspended in $2 \mathrm{ml} 50 \mathrm{~mm}$-Tris/5 mM-EDTA (pH 7.5), and sonicated (Branson Sonifier Cell Disruptor, model 200, with microtip) for $30 \mathrm{~s}$ at $50 \%$ pulse, with ice-water cooling. After centrifugation at $20000 \mathrm{~g}$ for $20 \mathrm{~min}$ at $4{ }^{\circ} \mathrm{C}$, the clear supernatant (lysate) was stored at $-70^{\circ} \mathrm{C}$.

The techniques of horizontal starch-gel electrophoresis and the demonstration of specific enzyme activity were similar to those described by Selander et al. (1986). The following 10 enzymes were assayed: phosphoglucose isomerase (PGI), NAD-dependent malate dehydrogenase (MDH), glucose-6-phosphate dehydrogenase (G6P), glutamic oxaloacetic transaminase (GOT), adenylate kinase (ADK), 6phosphogluconate dehydrogenase (6PG), leucylalanine peptidase-1 (PEP), leucine aminopeptidase (LAP), phosphoglucomutase (PGM), and glutamate dehydrogenase (GLD).

For each enzyme, distinctive mobility variants were designated as electromorphs and numbered in order of decreasing rate of anodal migration. Electromorphs of an enzyme were equated with alleles at the corresponding structural gene loci. Because all isolates showed activity for all 10 enzymes, the corresponding structural gene loci are presumed to be located on the chromosome rather than on plasmids.

Each isolate was characterized by its combination of alleles at the 10 enzyme loci, and distinctive profiles of electromorphs, corresponding to unique multilocus genotypes, were designated as electrophoretic types (ETs) (Selander et al., 1986). [The numerical designations of alleles and ETs used in the present study do not correspond to those used by Musser et al. $(1985,1986 a, 1988 b)$.]

Strains representing ETs 81 to 86 were also examined for electrophoretic variation of NADP-dependent malic enzyme, leucylalanine peptidase-2, fumarase, glyceraldehyde-3-phosphate dehydrogenase, nucleoside phosphorylase, catalase and carbamylate kinase.

Genetic diversity at an enzyme locus $(h)$ among either ETs or isolates was calculated from the allele frequencies as $h=\left(1-\Sigma x_{i}^{2}\right)[n /(n-1)]$, where $x_{i}$ is the frequency of the $i$ th allele and $n$ is the number of ETs (Selander et al., 1986). Mean genetic diversity per locus $(H)$ is the arithmetic average of $h$ values for all loci. Genetic distance $(D)$ between 
pairs of ETs was calculated as the number of loci at which dissimilar alleles were represented (mismatches), and clustering of ETs from a matrix of pairwise coefficients of genetic distance was performed by the average-linkage method (Selander et al., 1986).

DNA-DNA hybridization. Nine strains representative of ETs 81-85 and the $H$. influenzae type strain NCTC $8143^{\mathrm{T}}$ (National Collection of Type Cultures, Colindale, London, UK) were each cultured on six $15 \mathrm{~cm} \times 15 \mathrm{~cm}$ plates of chocolate agar medium (bioMérieux, Charbonnières les Bains, France). After incubation for $18-24 \mathrm{~h}$ at $37^{\circ} \mathrm{C}$ in $8 \% \mathrm{CO}_{2}$ and a visual check for purity, bacteria were harvested in $30 \mathrm{ml}$ buffer ( $40 \mathrm{~mm}$-Tris/2 mm-EDTA, pH 8 ). Cells were lysed by adding $220 \mu \mathrm{l}$ of a $25 \%(\mathrm{w} / \mathrm{v})$ aqueous solution of sodium dodecyl sulphate and $30 \mu \mathrm{l}$ of $2 \%(\mathrm{w} / \mathrm{v})$ pronase (Sigma). The mixture was incubated at $37^{\circ} \mathrm{C}$ overnight to achieve cell lysis. DNA was extracted and purified according to Brenner et al. (1982). Unlabelled DNA was sheared by sonication and dialysed overnight against $0.042 \mathrm{M}-\mathrm{NaCl}$, then stored at $4^{\circ} \mathrm{C}$. Native DNA of strain NCTC $8143^{\mathrm{T}}$ was labelled in vitro by nick translation (Brenner et al., 1982) with $\left[{ }^{3} \mathrm{H}\right]$ cytidine (Amersham). For DNA-DNA hybridization experiments, the $S 1$ nuclease method using DEAE-cellulose filters ( $2.4 \mathrm{~cm} \mathrm{DE} 81$ filter, Whatman) was performed as described by Popoff \& Coynault (1980). Labelled DNA (15 ng) and unlabelled DNA $(90 \mu \mathrm{g})$ were mixed in a solution containing $0.042 \mathrm{M}$ $\mathrm{NaCl}$ to a final volume of $0.5 \mathrm{ml}$, heat-denatured for $4 \mathrm{~min}$ at $100^{\circ} \mathrm{C}$, then incubated at $60^{\circ} \mathrm{C}$ for $16 \mathrm{~h}$.

The following values were determined: the relative binding $(\%)$ of DNA at $60{ }^{\circ} \mathrm{C}$; the temperature at which $50 \%$ of the reassociated DNA became hydrolysable by the $\mathrm{S} 1$ enzyme $\left(T_{\mathrm{m}}\right)$ (Crosa et al., 1973); and the difference $\left(\Delta T_{\mathrm{m}}\right)$ between homo- and heteroduplex $T_{\mathrm{m}}$ values, expressing the decrease of heteroduplex thermal stability.

\section{Results}

\section{Genetic diversity of isolates}

There were 112 serologically non-typable isolates, two isolates of serotype a and three isolates of serotype b. All 10 enzymes assayed were polymorphic for five to fourteen electrophoretically demonstrable variants, and the mean number of alleles per locus was 7.3. By comparing the allele profiles of isolates assayed for all 10 enzymes, 86 distinctive multilocus combinations or ETs were identified, among which mean genetic diversity per locus $(H)$ was 0.649 (variance 0.014 ) (Table 2). Thirteen of these ETs were represented by multiple isolates (range 2 to 18 ).

Genetic relationships among the 86 ETs are represented in the dendrogram shown in Fig. 1. The smallest observed genetic distance $(0 \cdot 10)$ corresponds to a singlelocus difference between ETs, and the largest distance $(0.84)$ corresponds to differences at 9 of the 10 loci assayed.

At a genetic distance of 0.60 , there were 10 clusters or lineages of ETs. ET 1 to ET 80 diverge from ET 81 to ET 86 at a genetic distance of 0.84 . Among the first group of ETs (ETs 1 to 80) there is a major cluster (cluster A in Fig. 1) of 69 ETs which diverges from ETs 70 to 80 at a genetic distance of 0.62 . Strains assigned to cluster A were of various biotypes: 8 isolates of biotype I, 44
Table 2. Genetic diversity $(h)$ at 10 enzyme loci in 86 ETs of $H$. influenzae isolated from genital and neonatal infections

\begin{tabular}{lcc}
\hline $\begin{array}{l}\text { Enzyme } \\
\text { locus* }\end{array}$ & $\begin{array}{c}\text { No. of } \\
\text { alleles }\end{array}$ & $\begin{array}{c}\text { Genetic } \\
\text { diversity }(h)\end{array}$ \\
\hline PGI & 14 & 0.858 \\
MDH & 7 & 0.715 \\
G6P & 8 & 0.784 \\
GOT & 5 & 0.671 \\
ADK & 5 & 0.496 \\
6PG & 7 & 0.546 \\
PEP & 7 & 0.734 \\
LAP & 7 & 0.590 \\
PGM & 5 & 0.630 \\
GLD & 8 & 0.471 \\
Mean & 7.3 & 0.649 \\
\hline \hline
\end{tabular}

* See Methods for explanation of abbreviations.

isolates of biotype II, 18 isolates of biotype III, 1 isolate of biotype IV, 6 isolates of biotype V, and 4 isolates of biotype VI. Isolates assigned to the various biotypes were distributed essentially randomly throughout cluster A. Isolates assigned to ETs 70 to 80 were also heterogeneous in biotype.

The most genetically divergent strains were assigned to ETs 81 to 86. Among this group of 6 ETs there is a major cluster (cluster B in Fig. 1) of 5 ETs (ETs 81 to 85) that were represented by 23 serologically non-typable isolates, all of which were of biotype IV. Seven of the isolates were recovered from patients in France, 15 isolates were cultured from individuals in the USA, and one isolate was recovered from a neonate in Canada. Analysis of these isolates for electrophoretic variation at seven other enzyme-encoding loci revealed little additional diversity, a result confirming the conclusion that this group is a closely allied cluster of genotypes.

\section{Genetic variation in relation to biotype}

Genetic diversity among ETs of each biotype is presented in Table 3, with the exception of biotypes $\mathrm{V}$ and VI, which are omitted because of small sample sizes. Mean genetic diversity per locus among ETs of each biotype varied from 0.263 in the case of biotype IV to 0.544 for biotype II, 0.588 for biotype I and 0.594 for biotype III. Thus, the biotype IV isolates were a genetically allied population. In addition, 23 of $25(92 \%)$ biotype IV isolates represented 5 ETs (ETs 81 to 85) clustering within the most genetically divergent group, and 18 of them $(78 \%)$ were assigned to a single multilocus genotype (ET 81). Nine strains representing ETs assigned to this cluster (five strains of ET 81 and one strain each of ETs 82 to 85 ) were further characterized by 


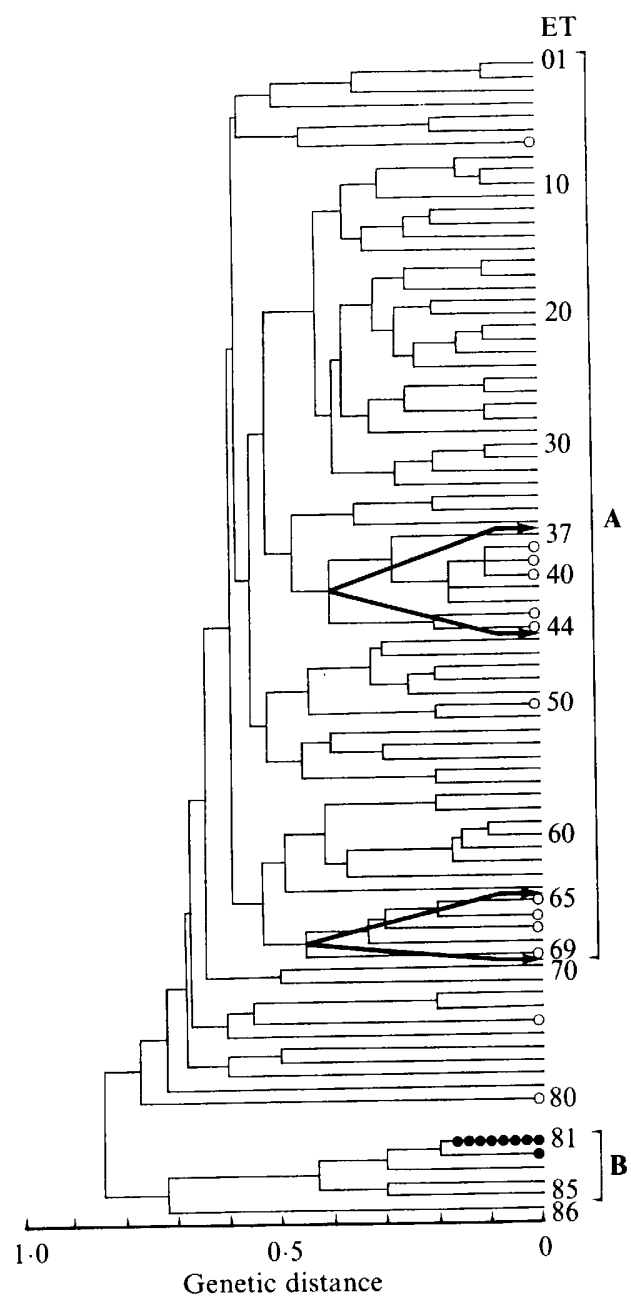

Fig. 1. Genetic relationships among 86 ETs of urogenital, maternal and neonatal $\boldsymbol{H}$. influenzae. The dendrogram was generated by the averagelinkage method of clustering from a matrix of coefficients of pairwise genetic distance (Selander et al., 1986) based on 10 enzyme loci. At a genetic distance of $\mathbf{0 . 6 0}$, there are 10 clusters or lineages of ETs. ETs 1 to 80 correspond to $H$. influenzae (sensu stricto) in which two clusters (ETs 37 to 44 and 65 to 69), comprising $69 \%$ of the strains recovered from patients with septicaemia and meningitis $(O)$, were identified. Isolates assigned to ETs 81 to 85 (cluster B) represent the putative new species of Haemophilus. Most of the strains (18/23) and eight of the nine invasive isolates (O) of this new species were assigned to ET 81.

Table 3. Genetic diversity per locus $(h)$ in $H$. influenzae isolates cultured from genital and neonatal infections, classified by biotype

\begin{tabular}{lcccc}
\hline \hline Biotype & $\begin{array}{c}\text { No. of } \\
\text { isolates }\end{array}$ & $\begin{array}{c}\text { No. of } \\
\text { ETs }\end{array}$ & $\begin{array}{c}\text { Mean no. } \\
\text { of alleles }\end{array}$ & $\begin{array}{c}\text { Mean genetic } \\
\text { diversity }\end{array}$ \\
\hline I & 12 & 12 & $3 \cdot 4$ & 0.588 \\
II & 48 & 39 & $5 \cdot 4$ & 0.544 \\
III & 22 & 18 & $4 \cdot 4$ & 0.594 \\
IV & 25 & 7 & $3 \cdot 1$ & 0.263 \\
\hline \hline
\end{tabular}

genomic DNA-DNA hybridization experiments. Estimates of the level of DNA relatedness of each isolate to the type strain of $H$. influenzae are shown in Table 4 . Strains of biotype IV assigned to ETs 81 to 85 were 52 to $68 \%$ (median $=60 \%$ ) related to the type strain, with $\Delta T_{\mathrm{m}}$ values between 6.5 and $8.3^{\circ} \mathrm{C}\left(\right.$ median $\left.=6.9^{\circ} \mathrm{C}\right)$. Hence, according to the generally accepted species criteria (Wayne et al., 1987), biotype IV strains of ETs 81 to 85 are incorrectly classified as $H$. influenzae and represent a previously unrecognized species.

Genetic variation of $H$. influenzae species (sensu stricto) (ETs 1 to 80) in relation to clinical episode

Strains responsible for upper genital infections (endometritis, pelvic inflammatory diseases and Bartholin's gland abscesses) did not cluster into a single phylogenetic line. The genetic diversity per locus $(0.594)$ and the frequency of alleles at the 10 enzyme loci among isolates recovered from these diseases were similar to those values recorded for the total sample, indicating that each of these types of disease was caused by strains belonging to a wide variety of chromosomal enzyme genotypes.

In contrast, 9 of the 13 non-serotypable strains isolated from cases of neonatal meningitis and/or mother-infant septicaemia were assigned to only two clusters of enzyme genotypes. The first cluster was composed of 8 strains in 8 ETs diverging at a genetic distance of 0.40 (ETs 37 to 44, Fig. 1) and comprised 5 invasive isolates. The second cluster contained 5 isolates representing 5 ETs diverging at a genetic distance of 0.45 (ETs 65 to 69), of which 4 isolates caused invasive disease episodes. Comparison of the allele frequencies of these 13 strains to those of strains isolated from heavily colonized neonates with no evidence of systemic infection (16 isolates assigned to 15 ETs distributed throughout the dendrogram in an apparently random fashion) revealed that these two populations differed significantly in the frequency of occurrence of certain alleles of MDH and PEP. Most notably, 10 of the 13 strains isolated from systemic infections possessed the 4 allele of MDH (Table 5).

Genetic variation of strains assigned to ETs 81 to 85 in relation to clinical episode

Of 23 strains belonging to this cluster, five of the French isolates were recovered from the gastric aspirates of heavily colonized neonates (Quentin et al., 1987) and one strain each was recovered from women with urethritis and endometritis. The USA isolates, from patients in a total of eight states, were cultured from cerebrospinal fluid ( 2 isolates), blood (6), amniotic fluid (3), placenta (1), scrotum (1), and one each from the cervix and vagina of women with post-partum sepsis. The single strain 
Table 4. Level of DNA relatedness between $H$. influenzae NCTC $8143^{\mathrm{T}}$ (the type strain) and nine biotype IV strains belonging to the putative cryptic species of Haemophilus isolated from neonatal and genital infections

\begin{tabular}{lcccc}
\hline \hline \multicolumn{1}{c}{$\begin{array}{c}\text { Source of } \\
\text { unlabelled DNA }\end{array}$} & Biotype & $\begin{array}{c}\text { Relative binding } \\
\text { to NCTC 8143T } \\
(\%)\end{array}$ & $T_{\mathrm{m}}$ & $\Delta T_{\mathrm{m}}$ \\
\hline Salmon testes & & $5 \cdot 6$ & - & - \\
NCTC 8143 & II & 100 & $87 \cdot 0$ & - \\
$\quad$ (1st determination) & & & & \\
NCTC 8143 & II & 100 & $87 \cdot 3$ & - \\
$\quad$ (2nd determination) & & & & \\
Strain 3N (ET 81) & IV & 63 & $80 \cdot 1$ & $6 \cdot 9$ \\
Strain 10N (ET 81) & IV & 68 & $80 \cdot 5$ & $6 \cdot 5$ \\
Strain 16N (ET 81) & IV & 67 & $80 \cdot 2$ & $6 \cdot 8$ \\
Strain 101 (ET 81) & IV & 60 & $80 \cdot 2$ & $6 \cdot 8$ \\
Strain 12N (ET 81) & IV & 55 & $80 \cdot 8$ & $6 \cdot 5$ \\
Strain 15N (ET 82) & IV & 52 & $80 \cdot 0$ & $7 \cdot 3$ \\
Strain 427 (ET 83) & IV & 67 & $80 \cdot 8$ & $6 \cdot 5$ \\
Strain 1610 (ET 84) & IV & 58 & $79 \cdot 4$ & $7 \cdot 6$ \\
Strain 26E (ET 85) & IV & 60 & $79 \cdot 0$ & $8 \cdot 3$ \\
Median & & 60 & $80 \cdot 2$ & $6 \cdot 9$ \\
\hline \hline
\end{tabular}

Table 5. Comparison of frequencies of alleles at $M D H$ and PEP enzyme loci in isolates of $H$. influenzae (ETs 1-80) in two populations of neonates: 16 neonates heavily colonized and 13 neonates with invasive disease (meningitis and/or septicaemia)

There was no significant difference for the eight other enzymes tested.

\begin{tabular}{|c|c|c|c|}
\hline $\begin{array}{l}\text { Locus } \\
\text { and alleles }\end{array}$ & $\begin{array}{l}\text { Neonates heavily } \\
\text { colonized }\end{array}$ & $\begin{array}{l}\text { Neonates with } \\
\text { invasive disease }\end{array}$ & $\chi^{2}$ test \\
\hline $\begin{array}{r}\text { MDH: } 1 \\
2 \\
3 \\
4 \\
5\end{array}$ & $\begin{array}{l}0.125 \\
0.187 \\
0.000 \\
0 \cdot 187 \\
0.500\end{array}$ & $\left.\begin{array}{l}0.077 \\
0.077 \\
0.077 \\
0.770 \\
0.000\end{array}\right\}$ & $\begin{array}{l}\chi^{2}=13.02 \\
P<0.02\end{array}$ \\
\hline $\begin{array}{ll}\text { PEP: } & 1 \\
& 2 \\
3 \\
4 \\
4 \\
5\end{array}$ & $\begin{array}{l}0.000 \\
0.375 \\
0.062 \\
0.500 \\
0.062\end{array}$ & $\left.\begin{array}{l}0.384 \\
0.384 \\
0.000 \\
0.154 \\
0.077\end{array}\right\}$ & $\begin{array}{l}\chi^{2}=10.62 \\
P<0.05\end{array}$ \\
\hline
\end{tabular}

from Canada was recovered from the CSF of a neonate.

Comparison of the allele frequencies of the nine strains recovered from mother-infant invasive infections to those of strains isolated from heavily colonized children revealed no significant differences.

\section{Discussion}

Our analysis demonstrated that a large variety of chromosomal genotypes of $H$. influenzae may cause urogenital, maternal and neonatal disease. Indeed, genetic diversity at enzyme loci in the present sample of isolates is fully equivalent to that recorded in the highly polymorphic species Escherichia coli and Neisseria meningitidis (Musser et al., 1986b).

The number of isolates examined in this study, and belonging to ETs 1 to 80 (Fig. 1) representing $H$. influenzae (sensu stricto), was adequate to permit a conclusion that for many of the non-invasive genital infections (e.g. endometritis, urethritis, bartholinitis and cervicitis) there was little, if any, obvious association with the genetic structure of the pathogen. For example, isolates from cervicitis and endometritis were distributed throughout most of the dendrogram, with no conspicuous pattern. However, for ETs 1 to $80,69 \%$ of strains 
responsible for invasive neonatal diseases were clustered in only two phylogenetic lineages characterized by a high frequency of occurrence of the 4 allele of MDH. As demonstrated for $E$. coli, certain alleles of metabolic enzymes may serve as molecular markers for clusters of unusually pathogenic isolates (Goullet \& Picard, 1986). Our results indicate that neonatal septicaemia and/or meningitis episodes are frequently due to strains of serologically non-typable $H$. influenzae assigned to two relatively unrelated clusters of allied genotypes.

Strains of the very divergent cluster B (ETs 81 to 85) were strongly associated with disease syndromes that are most unusual for Haemophilus: most isolates of these ETs were recovered from neonates or mothers with bacteraemia or from the gastric aspirates of neonates at risk of invasive infections. Lack of invasive disease in Tours caused by strains assigned to this group could perhaps be due to differences in clinical management between the USA and France, since strains from both countries were phenotypically (Quentin et al., 1989) and genotypically relatively homogeneous.

Multilocus enzyme electrophoresis estimates overall genetic relatedness among bacterial isolates from examination of allelic variation at a small fraction of the structural gene loci of the chromosomal genome. For strains of Legionella (Selander et al., 1985), E. coli and Shigella spp. (Ochman et al., 1983), Bordetella spp. (Musser et al., 1986b), Neisseria (Chun et al., 1985), and the oral streptococci (Gilmour et al., 1987), estimates of genetic relatedness based on multilocus enzyme electrophoresis have been shown to be strongly correlated $(r=0.8-0.9)$ with measures of similarity in total nucleotide sequences derived from DNA hybridization experiments. In general, for samples of 12 to 30 enzymes, strains diverging from one another at a genetic distance greater than 0.55 show a degree of nucleotide sequence similarity well below the $70 \%$ level now conventionally taken as the criterion of species limits in many groups of bacteria (Brenner, 1984; Wayne et al., 1987). ETs 81 to 85 diverge from other strains of $H$. influenzae at a genetic distance of 0.84 and the results from DNA hybridization experiments undoubtedly demonstrate that isolates assigned to these ETs represent a previously unrecognized Haemophilus species. The failure to identify ETs 81 to 85 among more than 2500 encapsulated isolates of $H$. influenzae (Musser et al., 1988a, b), 60 serologically nontypable isolates recovered from otitis and invasive diseases in children older than one month (Musser et al., $1986 a$ ), and more than 200 strains isolated from the respiratory tract and other infections (Mendelman et al., 1987; J. M. Musser, unpublished) strongly suggests that strains of this new species possess specific tropism for the urogenital tract.

For a variety of bacterial species, phenotypic or natural history correlates of genetic structure have been recorded (Selander \& Musser, 1990; Musser et al., 1987). The data presented here confirm earlier observations (Musser et al., 1985, 1986a) that, for $H$. influenzae, little information bearing on the genetic diversity and relationships of isolates is provided by biotyping. Epidemiological or other studies (e.g. antimicrobial testing: Quentin et al., 1988) employing biotyping as the sole criterion for grouping strains must be performed with the knowledge that strains classified in this manner are genetically heterogeneous. Strains of biotype IV belonging to the cryptic species of Haemophilus (ETs 81 to 85 ) constitute a notable exception. They are genetically relatively homogeneous, have identical outermembrane protein profiles which differ from these of $H$. influenzae and $H$. parainfluenzae, possess peritrichous fimbriation, and are, on average, more susceptible to quinolones than are isolates of $H$. influenzae (Quentin et al., 1988, 1989). Additional characterization will be necessary to complete the description of this newly identified species and will most probably reveal other additional genotypic and phenotypic differences when compared to populations of $H$. influenzae (sensu stricto).

We thank P. E. Pattison and S. Plisson for assistance in preparation of the manuscript and M. B. Kleiman who generously provided strains for analysis. This research was supported by grant AI-24332 from the National Institutes of Health (to R.K.S.) and by appropriation from University François Rabelais, Tours (to A.G.).

\section{References}

BrenNer, D. J. (1984). Family 1. Enterobacteriaceae Rahn 1937. In Bergey's Manual of Systematic Bacteriology, vol. 1, pp. 408-420. Edited by N. R. Krieg \& J. G. Holt. Baltimore: Williams \& Wilkins. BrenNer, D. J., McWhorter, A. C., Leete KNUTSON, J. K. \& Steigerwal, A. G. (1982). Escherichia vulneris: a new species of Enterobacteriaceae associated with human wounds. Journal of Clinical Microbiology 15, 1133-1140.

CAMpognone, P. \& Singer, D. B. (1986). Neonatal sepsis due to nontypable Haemophilus influenzae. American Journal of Diseases of Children 140, 117-121.

Chun, P. K., Sensabaugh, G. F. \& Vedros, N. A. (1985). Genetic relationships among Neisseria species assessed by comparative enzyme electrophoresis. Journal of General Microbiology 131, 31053115.

Crosa, J. H., Brenner, D. J. \& Falkow, S. (1973). Use of a singlestrand specific nuclease for analysis of bacterial and plasmid deoxyribonucleic acid homo- and heteroduplexes. Journal of Bacteriology 115, 904-911.

FRIESEN, C. A. \& CHO, C. T. (1986). Characteristic features of neonatal sepsis due to Haemophilus influenzae. Reviews of Infectious Diseases 8 , 777-780.

Gilmour, M. N., Whittam, T. S., Kilian, M. \& Selander, R. K. (1987). Genetic relationships among the oral streptococci. Journal of Bacteriology 169, 5247-5257.

Goullet, PH. \& PICARD, B. (1986). Highly pathogenic strains of Escherichia coli revealed by the distinct electrophoretic patterns of carboxylesterase B. Journal of General Microbiology 132, 1853-1858.

Holmes, R. L.. De Franco, M. \& OtTo, M. (1982). Novel method of biotyping Haemophilus influenzae that uses API 20. Journal of Clinical Microbiology 15, 1150-1152. 
KiLIAN, M. (1976). A taxonomic study of the genus Haemophilus, with the proposal of a new species. Journal of General Microbiology 93, 9-62.

KILIAN, M. (1980). Haemophilus. In Manual of Clinical Microbiology, 3rd edn, pp. 330-336. Edited by E. H. Lennette, A. Balows, W. J. Hausler, Jr \& J. P. Truant. Washington, DC: American Society for Microbiology.

Kleiman, M. B., Reynolds, J. K., Shreiner, R. L. \& Smith, J. W, (1983). Failure to demonstrate special virulence of nontypable Haemophilus influenzae biotype 4 in neonatal sepsis. Journal of Infectious Diseases 148, 615.

Mendelman, P. M., Chaffin, D. O., Musser, J. M., De Groot, R., Serfass, D. A. \& SelandeR, R. K. (1987). Genetic and phenotypic diversity among ampicillin-resistant, non- $\beta$-lactamase-producing, nontypeable Haemophilus influenzae isolates. Infection and Immunity 55, 2585-2589.

Musser, J. M., Granoff, D. M., Pattison, P. E. \& Selander, R. K. (1985). A population genetic framework for the study of invasive diseases caused by serotype $\mathrm{b}$ Haemophilus influenzae. Proceedings of the National Academy of Sciences of the United States of America 82, 5078-5082.

Musser, J. M., Barenkamp, S. J., Granoff, D. M. \& Selander, R. K. $(1986 a)$. Genetic relationships of serologically nontypable and serotype b strains of Haemophilus influenzae. Infection and Immunity 52, 183-191.

Musser, J. M., Hewlett, E. L., Peppler, M. S. \& Selander, R. K. $(1986 b)$. Genetic diversity and relationships in populations of Bordetella spp. Journal of Bacteriology 166, 230-237.

Musser, J. M., Bemis, D. A. Ishikawa, H. \& Selander, R. K. (1987). Clonal diversity and host distribution in Bordetella bronchiseptica. Journal of Bacteriology 169, 2793-2803.

Musser, J. M., Kroll, J. S., Moxon, E. R. \& Selander, R. K. (1988a). Clonal population structure of encapsulated Haemophilus influenzae. Infection and Immunity 56, 1837-1845.

Musser, J. M., Kroll, J. S., Moxon, E. R. \& Selander, R. K. $(1988 b)$. Evolutionary genetics of encapsulated strains of Haemophilus influenzae. Proceedings of the National Academy of Sciences of the United States of America 85, 7758-7762.

Ochman, H., Whittam, T. S., Caugant, D. A. \& Selander, R. K. (1983). Enzyme polymorphism and genetic population structure in Escherichia coli and Shigella. Journal of General Microbiology 129, 2715-2726.
Popoff, M. \& Coynault, C. (1980). Use of DEAE-cellulose filters in the S1 nuclease method for bacterial desoxyribonucleic acid hybridization. Annales de l'Institut Pasteur/Microbiologie 131A, 151155 .

Quentin, R., Goudeau, A., Burfin, E., Pinon, G., Berger, Ch., LAUGier, J. \& Soutoul, J. H. (1987). Infections materno-foetales à Haemophilus influenzae. La Presse Médicale 16, 1181-1184.

Quentin, R., Koubaa, N., Cattier, B., Gavignet, M. \& Goudeau, A. (1988). In vitro activities of five new quinolones against 88 genital and neonatal Haemophilus isolates. Antimicrobial Agents and Chemotherapy 32, 147-149.

Quentin, R., Musser, J. M, Mellouet, M., Sizaret, P. Y., Selander, R. K. \& Goudeau, A. (1989). Typing of urogenital, maternal and neonatal isolates of Haemophilus influenzae and Haemophilus parainfluenzae in correlation with clinical source of isolation and evidence for a genital specificity of $H$. influenzae biotype IV. Journal of Clinical Microbiology 27, 2286-2294.

SELANDER, R. K. \& MUSSER, J. M. (1990). The population genetics of bacterial pathogenesis. In Molecular Basis of Bacterial Pathogenesis. Edited by B. H. Iglewski \& V. L. Clark. Orlando: Academic Press (in the Press).

Selander, R. K., McKinney, R. M., Whittam, T. S., Bibb, W. F., Brenner, D. J., Nolte, F. S. \& Pattison, P. E. (1985). Genetic structure of populations of Legionella pneumophila. Journal of Bacteriology 163, 1021-1037.

Selander, R. K., Caugant, D. A., Ochman, H., Musser, J. M., GILMOUR, M. N. \& WhITTAM, T. S. (1986). Methods of multilocus enzyme electrophoresis for bacterial population genetics and systematics. Applied and Environmental Microbiology 51, 873-884.

W ALlaCe, R. J., JR, BAKER, C. J., QUinONES, F. J., Hollis, D. G., WeAVER, R. E. \& WIss, K. (1983). Nontypable Haemophilus influenzae (biotype 4) as a neonatal, maternal, and genital pathogen. Reviews of Infectious Diseases 5, 123-136.

WaYNe, L. G., BRenNer, D. J., Colwell, R. R., Grimont, P. A. D., KaNDler, O., KricheVSKy, M. I., MoORe, L. H., MOORE, W. E. C., MurRaY, R. G. T., Stackebrandt, E., StarR, M. P. \& TrüPER, J. G. (1987). Report of the ad hoc committee on reconciliation of approaches to bacterial systematics. International Journal of Systematic Bacteriology 37, 463-465. 